\title{
Abordaje "paso a paso" para el manejo de lactantes febriles
}

Step by step approach for the management of young febrile infants

Gómez, B y col. Pediatrics. 2016; 138, (2): e20154381

\section{Objetivo}

Validar un nuevo algoritmo para poder identificar un grupo de infantes con fiebre sin foco, de bajo riesgo, quienes podrían ser tratados con seguridad en forma ambulatoria sin someterse a una punción lumbar ni a tratamiento antibiótico empírico.

\section{Diseño, lugar y pacientes}

Estudio observacional prospectivo de validación que incluyó infantes de entre 21 y 90 días de vida con fiebre sin foco que asistieron a departamentos de emergencia pediátrica europeos entre septiembre de 2012 y agosto de 2014 .

Se incluyeron 2.185 infantes, excluyendo a quienes presentaran foco claro de infección, no tuvieran fiebre al ingreso a emergencias o refirieran fiebre subjetiva (no medida por termómetro), o ante la ausencia de alguna de las pruebas de laboratorio (hemocultivo, urocultivo, leucocituria, procalcitonina, proteína $\mathrm{C}$ reactiva $[\mathrm{PCR}]$ o recuento de neutrófilos).

\section{Medición de los resultados principales}

Los pacientes fueron evaluados y tratados de acuerdo con los protocolos locales. Se recolectaron datos de edad, sexo, duración de la fiebre, apariencia general del paciente al ingreso, antecedentes personales, resultados de los laboratorios y tratamientos recibidos. Los padres de los participantes recibieron un llamado telefónico un mes después de la visita inicial para evaluar el resultado del cuadro. De no poder establecer contacto, se verificaron los datos de la historia clínica electrónica.

Se comparó la exactitud diagnóstica del enfoque "Paso a Paso", los criterios de Rochester y los marcadores de laboratorio (PCR, procalcitonina y recuento de neutrófilos) para identificar pacientes con bajo riesgo para infección bacteriana invasiva (IBI), hemocultivo o cultivo de líquido cefalorraquídeo positivo.

Tabla 1: Sensibilidad, especificidad, valor predictivo positivo, valor predictivo negativo y coeficiente de probabilidad de cada enfoque para identificar infecciones bacterianas invasivas.

\begin{tabular}{|c|c|c|c|c|c|c|}
\hline & $\begin{array}{l}\text { Sensibilidad (\%) } \\
\text { (IC 95\%) }\end{array}$ & $\begin{array}{l}\text { Especificidad (\%) } \\
\text { (IC 95\%) }\end{array}$ & $\begin{array}{l}\text { Valor predictivo } \\
\text { positivo (\%) } \\
\text { (IC 95\%) }\end{array}$ & $\begin{array}{l}\text { Valor predictivo } \\
\text { negativo (\%) } \\
\text { (IC 95\%) }\end{array}$ & $\begin{array}{c}\text { Coeficiente de } \\
\text { Probabilidad } \\
\text { Positivo } \\
\text { (LR+) (IC 95\%) }\end{array}$ & $\begin{array}{c}\text { Coeficiente de } \\
\text { Probabilidad } \\
\text { Negativo } \\
\text { (LR-) (IC 95\%) }\end{array}$ \\
\hline Criterios de Rochester & $\begin{array}{c}81,6 \\
(72,2 \mathrm{a} 84,4)\end{array}$ & $\begin{array}{c}44,5 \\
(42,2 \mathrm{a} 46,6)\end{array}$ & $\begin{array}{c}5,7 \\
(4,6 \text { a 7,2) }\end{array}$ & $\begin{array}{c}98,3 \\
(97,5 \text { a } 99,0)\end{array}$ & $\begin{array}{c}1,47 \\
(1,32 \text { a } 1,64)\end{array}$ & $\begin{array}{c}0,41 \\
(0,26 \text { a } 0,65)\end{array}$ \\
\hline Marcadores de laboratorio & $\begin{array}{c}59,8 \\
(49,3 \text { a } 69,4)\end{array}$ & $\begin{array}{c}84,0 \\
(82,4 \text { a } 85,5)\end{array}$ & $\begin{array}{c}13,4 \\
(10,4 \text { a } 17,2)\end{array}$ & $\begin{array}{c}98,1 \\
(97,3 \text { a } 98,6)\end{array}$ & $\begin{array}{c}3,74 \\
(3,07 a 4,56)\end{array}$ & $\begin{array}{c}0,48 \\
(0,37 \text { a 0,62) }\end{array}$ \\
\hline Paso a Paso & $\begin{array}{c}92,0 \\
(84,3 \text { a } 96,0)\end{array}$ & $\begin{array}{c}46,9 \\
(44,8 \text { a 49,0) }\end{array}$ & $\begin{array}{c}6,7 \\
(5,4 \mathrm{a} 8,3)\end{array}$ & $\begin{array}{c}99,3 \\
(98,5 \text { a } 99,7)\end{array}$ & $\begin{array}{c}1,73 \\
(1,61 \text { a } 1,85)\end{array}$ & $\begin{array}{c}0,17 \\
(0,08 \text { a } 0,35)\end{array}$ \\
\hline
\end{tabular}

\section{Resultados principales}

De los 2.185 infantes incluidos, 504 fueron diagnosticados con infección bacteriana $(23,1 \%)$, incluyendo 87 con IBI $(3,9 \%)$ y 417 $(19,1 \%)$ con infecciones bacterianas sin bacteriemia (infección del tracto urinario y gastroenteritis). Aplicando la primera parte del algoritmo del enfoque "Paso a Paso" (estado general, edad y leucocituria) se identificaron el $79,3 \%$ de las IBI y el $98,5 \%$ de las infecciones bacterianas sin bacteriemia. Al agregar los parámetros de laboratorio (PCR, procalcitonina y recuento de neutrófilos), se identificaron el $99,93 \%$ de las IBI. De los 991 infantes que fueron clasificados de bajo riesgo siete infantes $(0,7 \%)$ tuvieron una $I B I$, seis de los cuales tenían fiebre de menos de dos horas de evolución. Ver tabla 1 para un resumen de los parámetros de precisión diagnóstica.

\section{Conclusiones}

Se validó el "Paso a Paso" como una herramienta valiosa para el manejo de lactantes febriles sin foco y se confirmó su precisión superior en la identificación de pacientes con bajo riesgo de IBI, en comparación con los criterios de Rochester y los marcadores de laboratorio.

\section{Conflictos de intereses / Financiamiento}

Los autores declaran no tener conflictos de intereses. El estudio no tuvo financiamiento externo. 


\section{Comentario}

Los niños febriles menores de 90 días de vida son una población de riesgo. La incidencia de infección bacteriana grave en esta población ha sido estimada en un 6 a $10 \%{ }^{2}$.

A todos los lactantes menores de 3 meses con fiebre sin foco debería realizárseles las pruebas de sepsis ${ }^{3}$, dentro de los que se encuentran los criterios de Rochester, los marcadores de laboratorio y el nuevo enfoque "Paso a Paso". Este último incluye criterios clínicos y de laboratorio aplicados secuencialmente en orden de relevancia clínica. El primer paso es la valoración del estado general del paciente, parámetro que se asocia a un mayor riesgo para infecciones bacterianas ${ }^{4}$. El segundo ítem es la edad menor a 21 días. El tercero es la leucocituria que permite identificar a los pacientes con alta probabilidad de tener una infección urinaria. Según el presente estudio, con estos tres parámetros se podrían identificar aproximadamente el $80 \%$ de las infecciones bacterianas graves.
Con respecto a los marcadores de laboratorio, la procalcitonina es el mejor marcador de infección bacteriana grave ${ }^{5}$. Los pacientes con riesgo intermedio son los que solo tienen elevados la PCR y el recuento absoluto de neutrófilos ${ }^{6}$. Si el paciente no presenta ninguno de estos parámetros clínicos ni de laboratorio se clasifica como paciente de bajo riesgo.

\section{Conclusiones del Comentador}

Este algoritmo podría ser muy útil para identificar a las pacientes febriles menores de tres meses con bajo riesgo para bacteriemia. Se debería ser cuidadoso al aplicarlo en los pacientes menores de 28 días, así como también en aquellos lactantes con una escasa duración del tiempo de evolución de la fiebre, ya que algunos pacientes que tenían un periodo de corta evolución fueron erróneamente calificados como de bajo riesgo (menos de 2 horas).

Cecilia Picolla [Servicio de Pediatría. Hospital Italiano de San Justo. cecilia.picolla@hospitalitaliano.org.ar]

Picolla C. Abordaje "Paso a Paso" para el manejo de lactantes febriles. Evid Act Pract Ambul. 2018;21(1):20-21 Comentado de: Gómez B, Mintegi S, Bressan S, y col. Validation of the "Step-by-Step" Approach in the management of Young Febrile Infants. Pediatrics. 2016; 138(2): e20154381. PMID: 27382134

Referencias Bibliográficas

1. Bermejo P, Fiebre en Niños de 30 a 90 días. En: Straface R; Fiebre en Pediatría, $1^{\circ}$ edición, Buenos aires, Fundasap, 2006, 47-49

2. Arora R, y col. Evaluation of Child with fever without source. Review of literature and update. Pediatr Clin North Am. 2013; 60:1049-62.

3. Ruiz Contreras J, y col. Abordaje del niño con fiebre sin foco. En AEPap ed. Curso de actualización Pediátrica 2015. Madrid: Lúa Ediciones 3,0; 2015. p 31-8

4. Gómez B, y col. Blood culture and bacteremia predictors in infants less than three months of age with fever without source. Pediatr Infect Dis J. 2010; 29 (1):43-47

5. Dandona P, y col. Procalcitonin increase after endotoxin injection in normal subjects. J Clin Endocrinol Metab. 1994 Dec;79(6):1605-8

6. Bonsu BK, ycol. Identifying febrile Young infants with bacteremia: is the peripheral White blood cell count an accurate screen? Ann Emerg Med. 2003; 42(2):216-225

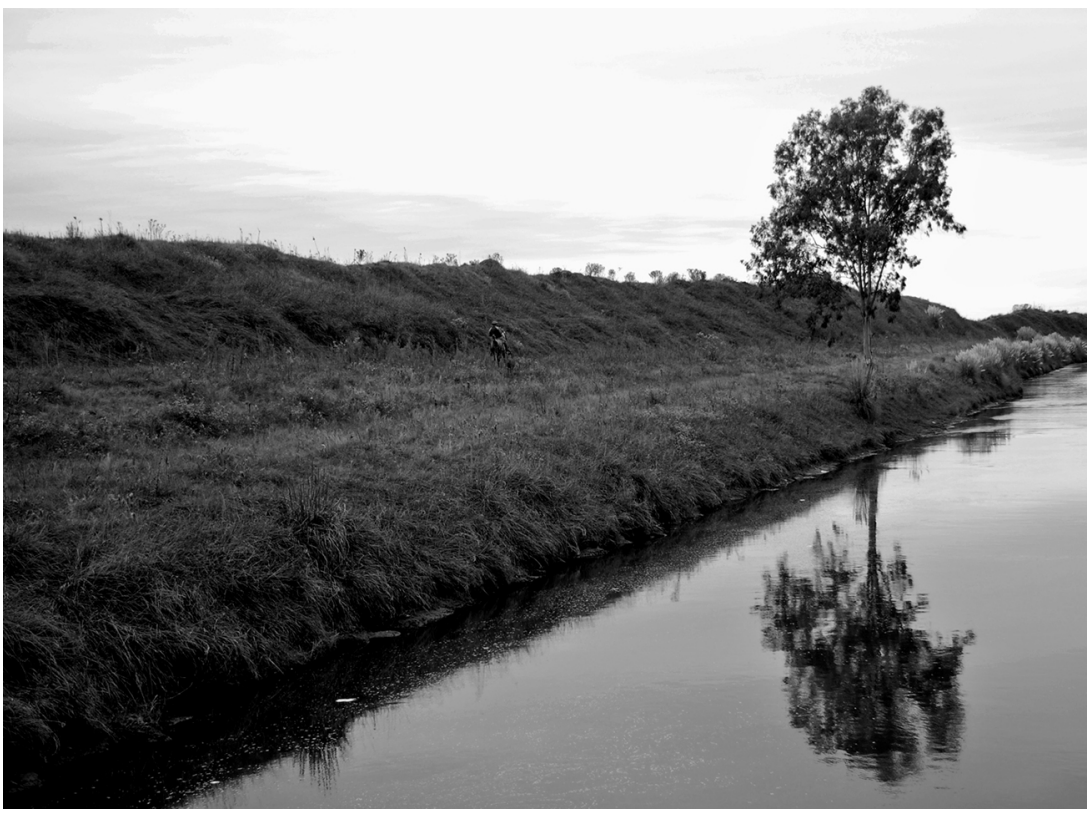

Cortesía de Silvia Spina 